\title{
SERVICE OF PROCESS ON FOREIGN CORPORATIONS: NORTH CAROLINA ADOPTS A RESTRICTIVE INTERPRETATION
}

\author{
$\mathbf{J}$ \\ URISDICTION of state courts over foreign corporations has for years \\ been the subject of extensive litigation. ${ }^{1}$ While the question ultimately \\ involves the satisfaction of due process requirements of the fourteenth \\ amendment, ${ }^{2}$ the decisions evince a variety of conflicting views as to \\ what this satisfaction entails. \\ Judicial application of the traditional concept of service of process on \\ natural persons to the fictitious corporate personality ${ }^{3}$ was originally lim- \\ ited to suits brought in the state of incorporation. Practical necessity, \\ however, made this position untenable in view of the increasing ex- \\ pansion and complexity of corporate activity. ${ }^{5}$ Consequently, theories of \\ "implied consent" and "presence" were propounded, the requirements
}

\footnotetext{
${ }^{2}$ A problem not contemplated within the scope of this note arises where state courts assert narrower jurisdiction over foreign corporations than that asserted by federal courts in comparable cases. In that situation, a federal judge would face the problem of a choice of law in delineating the jurisdiction of his court, which involves the question of the applicability of Erie R.R. v. Tompkins, 304 U.S. 64 (1938). See K. Shapiro, Inc. v. New York Central R.R., 152 F. Supp. 722 (E.D. Mich. 1957).

'See Riverside and Dan River Cotton Mills v. Menefee, 237 U.S. I89 (1915); Pennoyer v. Neff, 95 U.S. $71_{4}$ ( 1877 ).

${ }^{3}$ Some of the problems in this area have undoubtedly arisen because of a difficulty in applying jurisdictional ideas developed when the courts dealt only with natural persons to the idea of a corporate personality. Service of process on a corporation presents different problems than those arising when a natural person is served. Thus, when the same rules are applied to two situations so different in fact, it is to be expected that some difficulty will result.

'Bank of Augusta v. Earle, 38 U.S. (13 Pet.) 517, 588 (1839).

8 "This doctrine of the exemption of a corporation from suit in a state other than that of its creation was the cause of much inconvenience, and often of manifest injustice. The great increase in the number of corporations of late years, and the immense extent of their business, only made this inconvenience and injustice more frequent and marked." St. Clair v. Cox, 106 U.S. 350, 355 (1882).

- "If a state permits a foreign corporation to do business within her limits, and at the same time provides that in suits against it for business there done, process shall be served upon its agents, the provision is to be deemed a condition of the permission; and corporations that subsequently do business in the state are to be deemed to assent to such condition as fully as though they had specially authorized their agents to receive service of the proress." Id. at 356 . See also, Insurance Co. v. French, 59 U.S. (18 How.) 404 (1855).

7 "A foreign corporation is amenable to process to enforce a personal liability, in
} 
of which are satisfied when it is found that the corporation is "doing business" in a particular state. ${ }^{8}$

A further progression was made in International Shoe Co. v. State of Washington, where the United States Supreme Court characterized the "presence" theory as begging the question ${ }^{10}$ and the "implied consent" theory as a legal fiction ${ }^{11}$ and held that due process requires only certain minimum contacts so that the maintenance of the suit does not offend "traditional notions of fair play and substantial justice."12 That the International Shoe case ${ }^{13}$ has not met with uniform interpretation, however, is abundantly illustrated by recent decisions, which may be

the absence of consent, only if it is doing business within the state in such manner and to such extent as to warrant the inference that it is present there." Philadelphia \& Reading R.R. v. McKibbin, 243 U.S. 264, 265 (1917). See also, Green v. Chicago, Burlington, and Quincy R.R., 205, U.S. 530 (1906).

'St. Clair v. Cox, 106 U.S. 350 (1882); International Harvester Co. v. Kentucky, 234 U.S. 579 (1914); Green v. Chicago, Burlington and Quincy R.R., 205 U.S. 530 (x906). Both of the excerpts quoted in notes 6 and 7 , supra, assume that the doing of business by a corporation satisfies the requirements of the theory in question.

The following portion of the opinion in the Green case is an indication of the factors considered by courts in determining whether a corporation is doing business in a state: " $A$ single isolated transaction would not nsually be sufficient, although the transaction inight be of such magnitude, and involve so many acts as to be an exception to such a rule. A series of transactions in the state long continued usually amounts to the carrying on of business, but here again the acts might of of such a character as, for example, the mere solicitation by traveling salesmen as not to cone within the rule . . certain elements . . a are usually considered to indicate the carrying on of a business, as e.g.

The establishment of a permanent office to which all persons having business with the corporation may come.

The employment of an agent located within the state who is advertised as a general agent of the corporation for such bnsiness as it transacts in the state.

The continuous making within the state of contracts binding on the corporation." 205 U.S. at 531 . See also, Isaacs, $A n$ Analysis of Doing Business, 25 Colvm. L. REv. 1018 (1925); Note, 39 ILL. L. REv. 424 (1945). A more comprehensive discussion of the historical developinent of a state's jurisdiction over foreign corporations can be found in Colnment, 37 Cornell L.Q. 458 (1952). See also, Note, 20 TUL. L. REv. 437 (1946).

326 U.S. 3 10 (1945).

${ }^{10}$ 'To say that the corporation is so far 'present' there as to satisfy due process requireinents . . . is to beg the question to be decided." Id. at 316 .

12 "True, some the decisions holding the corporation amenable to suit have been supported by resort to the legal fiction that it has given its consent to service and suit. ..." Id. at $3 \times 8$.

1s Id. at 316. Another significant part of the opinion states that, "An estimate of the inconveniences' which would result to the corporation from a trial away from its 'home' or principal place of business is relevant in this connection." Id. at 317 .

${ }^{18}$ See Comments, 16 U. CHI. L. REv. 523 (1949); 18 U. CHI. L. Rev. 792 (1951); 37 CORNELL L.Q. $45^{8}$ (1952), for analyses of the International Shoe case. 
placed into two broad and divergent categories. ${ }^{14}$ Erlanger Mills, Inc. v. Cohoes Fibre Mills, Inc., ${ }^{15}$ is representative of the view that the "minimum contacts" test is simply a restatement of the conceptualistic ideas of the past and implies that the question of "presence" is still of primary importance. On the other hand, there is the view, which has had some significant judicial acceptance, that the International Shoe case represents a clear departure from the traditional concepts. ${ }^{16}$ Under this approach, interpretation of the "minimum contacts" or "fairness" test would call for reference to the specific mterests in conflict in each particular case. ${ }^{17}$

24 Travelers Health Ass'n. et al. v. Virginia ex rel. State Corp. Comm'n., 339 U.S. 643 (1950) deals with this problem, but does not clearly indicate what significance the Supreme Court attaches to International Shoe. The opinion of the Court, which does not seem to require "presence," was accepted by only four justices, while four, believing "presence" to be requisite, dissented. Justice Douglas concurred in an opinion which leaves some doubt as to the significance he attached to International Shoe.

${ }^{15}{ }_{239}$ F.2d 502 (4th Cir. 1956). Significant langnage in the Erlanger Mills case described the "minimum contacts" test as, "not so much an innovation on due process as it was a rephrasing of the prevailing fictional tests, . . . long employed." 239 F.2d at 506.

${ }^{20}$ "Both the broad test stated in the International Shoe case and its general language seem clearly to imply that courts may constitutionally exercise greater freedom than they might have formerly in subjecting foreign corporations to in personam actions." Comment, 36 U. CHI. L. REv. 523, 525 (1949).

The rationale of the International Shoe case was applied in the following cases to hold that an assertion of jurisdiction over the defendants in question did not violate due process: Smythe v. Twin State Improvement Corp., 80 A.2d 664 (Vt. 1951) (defendant's single act in the state was the commission of a tort against the plaintiff); French v. Gibbs Corp., 189 F.2d 78y (2d Cir. 1951) (defendant had been doing business in the state until a month before the suit was brought, but when the suit was brought defendant's activities were not deemed sufficient to constitute "doing business"); Latimer v. S/A Industrias Reunidas F. Matarazzo, 175 F.2d 184 (2d Cir. 1949) (defendant bought and sold goods in the state only on rare occasions); Green v. Equitable Powder Mfg. Co., 99 F. Supp. 237 (W.D. Ark. 195I) (defendant's employees solicited business and exhibited products in the state); Johns v. Bay State Abrasive Products Co., 89 F. Supp. 654 (D. Md. 1950) (isolated act of defendant's agent was the basis of a tort); Kilpatrick v. Texas \& P. Ry., I66 F.2d 788 (2d Cir. 1948) (defendant maintained an office with eight employees in the state to solicit passenger and freight business); Bach v. Friden Calculating Machine Co., 167 F.2d 679 (6th Cir. 1948) (defendant had an employee in the state who sold, serviced, and repaired its products); Rayce v. Chicopee, 148 F. Supp. 588 (S.D.N.Y. 1957) (defendant corporation inaintained a subsidiary corporation in the state to act as a solicitor of orders which were accepted or rejected outside the state); W.H. Elliot and Sons Co. v. Nuodex Products Co., 243 F.2d 116 (1st Cir. 1957) (defendant corporation marketed its products through another independent corporation, but promoted its product by advertising in the state and registered its product under the state's Economic Poisons Law).

${ }^{27}$ For example, the expense and inconvenience of the corporation in defending 
This was the position apparently adopted by the North Carolina - legislature when it enacted G.S. 55-38.I, liberalizing that state's require- ments for service of process on a foreign corporation. ${ }^{18}$ Subsection (a) (3) of this statute provides for service on a foreign corporation when a cause of action arises:

out of the production, manufacture; or distribution of goods by such corporation with the reasonable expectation that those goods are to be used or consumed, regardless of how or where the goods were produced, manufactured, marketed, or sold or whether or not through the medium of independent contractors or dealers.

This section was declared unconstitutional in Putnam v. Triangle Publications, ${ }^{10}$ on the facts of that case, ${ }^{20}$ as being violative of the due process clause of the fourteenth amendment. There, the defendant, a Delaware corporation, with its principal offices in Pennsylvania, published magazines which were. sold to eighteen independent wholesale newsdealers in North Carolina. Title passed when the magazines were delivered to the carrier in Pennsylvania, and payments were made at defendant's Pennsylvania or District of Columbia offices. Three of defendant's representatives were sent into North Carolina two to five times a year to promote-sales to television and news dealers. Plaintiff sued in North Carolina for libel and invasion of privacy as a result of an article published in one of defendant's magazines, relying upon subsection (a) (3) to support the court's jurisdiction over the defendant. The court, however, held that the defendant did not have sufficient ties or contacts with North Carolina to make it amenable to suit in that state.

This result does not comport with the general tenor of decisions in other forums which have upheld jurisdiction founded solely upon situs of contract ${ }^{21}$ or representation in the state by a part-time manufacturer's

the suit would be measured against the convenience of the plaintiff in having a local forum where his damages could be compensated.

${ }^{18}$ Some other state statutes dealing with this problem are: ALA. CODE tit. 7, § 199 (Supp. 1953); ARK. Stat. ANN. \$ 27-340 (1947); Ill. Stat. ANn. § 104.017 (Jones Supp. 1955); MD. ANN: CODE art. 23, § 88 (1951); VT. STAT. \& 1562 (1947); W. VA. CODE ANN. \& 3091 (Supp. 1953).

10245 N.C. 432,96 S.E.2d 445 (1957).

20245 N.C. at 443,96 S.E.2d at 454 .

${ }^{21}$ Compania de Astral, S.A. v. Boston Metals Co., 205 Md. 237, 107 A.2d 357 (1954). Jurisdiction here was based on the Maryland statute. MD. ANN. CoDE art. 23, \&88 (1951). 
agent. ${ }^{22}$ At least one court has adopted a "benefit of the market" test to uphold jurisdiction over a foreign corporation whose only contact with the forum was through a dealer who sold and serviced the defendant's products. ${ }^{23}$ And the Court of Appeals for the Second Circuit has held that important considerations in the jurisdictional problem are the "convenience of the obligee against the burden of the corporation," emphasizing fairness, in the light of the facts of the case, ${ }^{25}$ rather than the measurement of the defendant's acts within the state in an effort to determine whether it was "present."26

${ }^{22}$ Nugey v. Paul-Lewis Laboratories, 132 F. Supp. 448 (S.D.N.Y. 1955). Perhaps it is also significant that the manufacturer's respresentative derived only five to ten percent of his income from selling for the foreign corporation.

${ }^{23}$ Eclipse Fuel Engineering Co. v. Superior Court, 307 P.2d 739 (Cal. 1957). The opinion stated that the distinction between agent and independent contractor was unimportant in deciding the jurisdiction question if "... the representation which petitioner maintained in the state gave it ... the benefits and advantages it would have enjoyed by operating through its own office or paid sales force. ..." Id. at 742 [citing Sales Affiliates, Inc. v. Superior Ct., 96 Cal. App.2d 134, 136, 214 P.2d 541, 542 (1950)]. Note that in the instant case the imdependent contractor system of selling used by Triangle Publications gave it the benefit of the North Carolina market.

36 Bomze v. Nardis Sportswear Inc., 165 F.2d 33 (2d Cir. 1948). This same court, speaking through the same judge, has analogized these considerations to those in the issue of "forum non conveniens." Kilpatrick v. Texas \& P. Ry., 166 F.2d 788 (2d Cir. 1948), cert. denied, 335 U.S. 814 (1948). This analogy is criticized in Note, 35 N.C.L. REV. 546 (1957). It would appear, however, that since the emphasis is on convenience and fairness in both situations, the analogy has merit, although it is possible to make technical distinctions between the two.

${ }^{35}$ It must not be supposed that the cases in this second group have allowed out-ofstate plaintiffs to sue out-of-state corporations in the courts of a neutral state, or have allowed residents of a state to sue foreign corporations which had no contacts at all with the state. The situation is, rather, that of residents of a state suing corporations, which have certain contacts with the state, for damages which the plaintiff probably suffered within the confines of the state.

${ }^{20}$ The Triangle case becomes even more questionable when viewed in light of a recent United States Supreme Court decision, McGee v. International Life Ins. Co., 355 U.S. 220 (1957). There the plaintiff's son had entered into an insurance contract with an Arizona insurance company whose obligations were subsequently assumed by defendant, a Texas insurance company. When defendant refused to pay plaintiff's claim, plaintiff sued and recovered in a California court. Neither the Arizona corporation nor the defendant had ever had any offices or agents in California, and there was no proof that the defendant had ever solicited or done any insurance business. in California apart from the policy in qnestion. Jurisdiction was based on a statute which subjected foreign corporations to suit in California on insurance contracts with residents of that state. CAL. INs. CodE $\$ \S$ r610-162o.

Unable to collect her judgment in California, the plaintiff sued on it in Texas where enforcement was denied, the Texas court holding it void under the fourteenth amendment. McGee v. International Life Insurance Co.. 228 S.W.2d 579 (Tex Civ. 
Thus, it would appear that the Putnam decision is subject to valid criticism. ${ }^{27}$ The plaintiff suffered his injury in North Carolina, where his reputation was harmed by the allegedly libelous article in the defendant's magazine; most of the witnesses would probably have been from North Carolina; ${ }^{28}$ and the law of libel as determined by North Carolina courts would have been applicable. ${ }^{29}$ Moreover, it is questionable whether a corporation should benefit from a local market and yet remain immune from suits instituted by persons in the locality who are damaged by its products. This case indicates that corporations can tap the North Carolina market without fear of suit by marketing their products through nominally independent contractors rather than agents. The end result is that a corporation, through the careful selection of marketing methods, and by virtue of this alone, can determine whether or not it will be amendable to suit in a particular jurisdiction. It seems anomalous that due process, a concept with roots in fairness and justice, should bar a suit in the most convenient forum in the absence of mani:fest unfairness and injustice to the defendant.

It would appear, therefore, that the effectiveness and utility of the North Carolina statute, representing as it does an attempt to replace such fictitional and conceptualistic tests as that of corporate "presence" with certain specific rules which are more compatible with the complexities of a modern economy, has been unnecessarily curtailed. Under the authority of the International Shoe case, the court would have been justified in holding it coustitutional on the facts of the Putnam

App. 1956). In reversing, the United States Supreane Court found what it considered a clearly discernible trend toward expanding the permissible scope of state jurisdiction over foreign corporations and other non-residents. This trend was explained as partially the result of the increasing nationalization of commerce and the improvennents in transportation and communication which make it easier for a party sued to defend himself where he engages in econounic activity. The court also mentioned the availability of witnesses and the disadvantage to residents in having to follow an insurance company to a distant state in order to hold it legally accountable as being pertinent factors in determining whether due process was satisfied.

${ }^{27}$ But cf. Note, 35 N.C.I. REV: 546 (1957) viewing this decision with favor.

"For example, the plaintiff must prove the lowering of his esteem in the eyes of a substantial group in order to establish a case of libel. This element of the tort of libel is satisfied usually "... if he is lowered in the esteem of any substantial and respectable grotrp. ..." Prosser, TorTs § 92, p. 577 (2d ed, 1955).; Being a resident of North Carolina, plaintiff's reputation must have been lowered in the eyes of fellow North -Carolina residents. - Their testimony would have to be used to establish this element of plaintiff's case. :

20 Restatement, Confuict of Laws; $\$ 377,378$ (1934). 
case. $^{80}$ Nor does the judicial spectre of a myriad of small suits brought to harass a corporation engaged in multistate activity appear other than chimerical when it is realized that such suits may be dismissed for lack of jurisdiction under the "minimum contacts" or "fairness" test. Furthermore, there is no well-founded reason why a corporation should not have to defend in the forum where it has caused injury, regardless of the number of suits which might result.

Mature reflection upon the object of the more liberal approach to this problem, as illustrated by the decisions of other courts and by the policy factors which impelled the enactment of the statute in question, makes manifest the need for a reappraisal of subsection (a) (3).

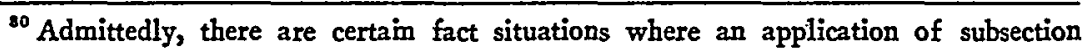
(a) (3) would be unconstitutional. An example, perhaps, is the hypothetical case posed by Judge Sobeloff in Erlanger Mills v. Cohoes, 239 F.2d 502 (4th Cir. 1956). In his example, a service station in Califorriia sells a tire to a car with a Pennsylvania license plate. The seller could be expected to anticipate the use of the tire in Pennsylvania, but one would hesitate to argue that he should have to defend a suit in Pennsylvaria if the tire were defective. Here, the considerations of convenience and fairness would be on the side of the seller, who has only a modicum of contact with Pennsylvania.

"The old "presence" theory does not seem to offer any greater degree of protection against these so called "nuisance suits" than the "minimum contracts" of "fairness". test. Even under the "presence" test the corporation's attorney is taking a chance if he refuses to go to a state and defend against a suit because he believes the state has no jurisdiction over his client. The law on this point is not so clear that the attorney can easily tell whether a state really has jurisdiction over his client or not. The real difference in the two approaches to the problem is that the attorney's considerations are, at least, partially conceptual under the "presence" test, while under the "minimnm contacts" test the attorney is primarily concerned with the factors of convenience and fairness to all parties involved. 